\title{
Life cycle of Ornithodoros rostratus (Acari: Argasidae) under experimental conditions and comments on the host-parasite relationship in the Pantanal wetland region, Brazil
}

\author{
Carla Carolina Dias Uzedo Ribeiro • João Luiz Horácio Faccini • \\ Paulo Henrique Duarte Cançado • Eliane Mattos Piranda • \\ Darci Moraes Barros-Battesti • Romário Cerqueira Leite
}

Received: 25 October 2012/Accepted: 1 February 2013/Published online: 1 March 2013 (C) Springer Science+Business Media Dordrecht 2013

\begin{abstract}
The genus Ornithodoros is represented by 15 species in Brazil, on which no detailed life cycle studies have been published, except for $O$. talaje and $O$. mimon. The aim of the present study was to evaluate life cycle parameters of $O$. rostratus based on ticks collected in the Pantanal wetland region of the state of Mato Grosso do Sul, Brazil, using domestic rabbits as experimental hosts. The periods of pre-attachment and feeding of the larvae lasted an average of $39 \mathrm{~min}$ (range 15-76 min). Five or six nymphal instars were found. The emergence of adults started with N3 in the following sequence: N3-two males; N4-13 males; N5-three males and 16 females; and N6-two females. Mean weight of N4 that molted to males was $31.7 \pm 13.6 \mathrm{mg}$, whereas mean weight of N5 that molted to females was $100.1 \pm 36.2 \mathrm{mg}$. The overall sex ratio was $1: 1$. Oviposition lasted 14 days, with a sharp decline beginning with the 7 th day. The overall duration of the life cycle of $O$. rostratus ranged from approximately 66 to 136 days. Comments on the tickhost relationship in the Pantanal region are offered.
\end{abstract}

Keywords Ornithodoros rostratus $\cdot$ Argasidae $\cdot$ Life cycle $\cdot$ Experimental · Host-relations

C. C. D. U. Ribeiro · J. L. H. Faccini $(\bowtie)$

Departamento de Parasitologia Animal, Instituto de Veterinária,

Universidade Federal Rural do Rio de Janeiro, Seropédica, RJ 23890-000, Brazil

e-mail: faccinijlh@globo.com

P. H. D. Cançado

Embrapa Gado de Corte, Campo Grande, MS, Brazil

E. M. Piranda

Centro de Ciências Biológicas e da Saúde, UFMS, Campo Grande, MS, Brazil

D. M. Barros-Battesti

Laboratório de Parasitologia, Instituto Butantan, São Paulo, SP, Brazil

R. C. Leite

Escola de Veterinária, Universidade Federal de Minas Gerais, Minas Gerais, MG, Brazil 


\section{Introduction}

The genus Ornithodoros is represented by at least 114 species of ticks, 53 of which are found in the Neotropics and 15 occur in Brazil (Barros-Battesti et al. 2012; Dantas-Torres et al. 2012): $O$. brasiliensis Aragão, O. capensis Neumann, O. cavernicolous Dantas-Torres, Venzal and Labruna, O. fonsecai Labruna and Venzal, O. hasei Schulze, O. jul Schulze, O. marinkellei Kohls, Jones and Clifford, O. mimon Kohls, Jones and Clifford, $O$. nattereri Warburton, $O$. rondoniensis Labruna, Terrassini, Camargo, Brandão, Ribeiro and Estrada-Peña, O. rostratus Aragão, O. rudis Karsh, O. setosus Kohls, Jones and Clifford, O. stageri Cooley and Kohls and O. talaje Méneville-Guérin.

Except for O. talaje (Schumaker and Barros, 1995) and O. mimon (Landulfo et al. 2012), no detailed studies on the life cycle of remaining species have been published. Partial information on the biology of $O$. brasiliensis has been published by Davis (1952) using guinea pigs as the host and O. rostratus by Brumpt (1915) using dogs and chickens as hosts, Guglielmone and Hadani (1980) using guinea pigs and Venzal and Estrada-Peña (2006) using rabbits.

During a study on the ecology of free-living stages of ticks in the region of Nhecolândia, Pantanal, Brazil (Cançado et al. 2008), 114 specimens of $O$. rostratus were collected (larvae, nymphs and adults) from a rustic stable (Fig. 1b) using a $\mathrm{CO}_{2}$ trap for $2 \mathrm{~h}$ each on two trips (November 2006 and August 2007), suggesting that this species is common in the area. The stable was used to house a milking cow and her calf to produce milk for the farm employees. This information and absence of detailed studies on the life cycle of $O$. rostratus help us decide to describe in detail the life cycle of this tick and planning new trips to the Embrapa farm for further observations on the species of concern.

It is also worth of note that Almeida et al. (2012) recently found genes of Coxiella similar to $C$. burnetti in specimens of $O$. rostratus collected also from the Embrapa farm.

\section{Materials and methods}

Life cycle

The life cycle study was conducted at the Department of Animal Parasitology, Universidade Federal Rural do Rio de Janeiro (UFRRJ, Brazil). The ticks used in the experiment were from a colony established from ticks collected from a rustic cattle stable on the Embrapa farm located in the Nhecolândia region $\left(19^{\circ} 03^{\prime} \mathrm{S}, 56^{\circ} 47^{\prime} \mathrm{W}\right)$ of the Pantanal wetland region in the state of Mato Grosso do Sul, Brazil. Specific identification was confirmed by morphological and molecular methods. The nomenclature of the species is in agreement with the list of valid species proposed by Guglielmone et al. (2010).

The larvae, nymphs and adults aged 35-45 days old were fed on 17 domestic rabbits (Oryctolagus cuniculus) crossbred from California and New Zealand. The rabbits were of both sexes, aged between 60 and 90 days and without previous contact with ticks. Each rabbit was replaced every infestation cycle (larva to adult). Throughout the experiment, all animals were housed in individual cages with access to food and water ad libitum. All tick stages were fed on the back of the rabbits at an ambient temperature of $25 \pm 10{ }^{\circ} \mathrm{C}$ and under natural light.

Ticks from first and second laboratory generations were used. Different samples of larvae, nymphs and females which had fed only once, were randomly selected from the colony, considering difficulty in obtaining enough specimens from the same generation due 

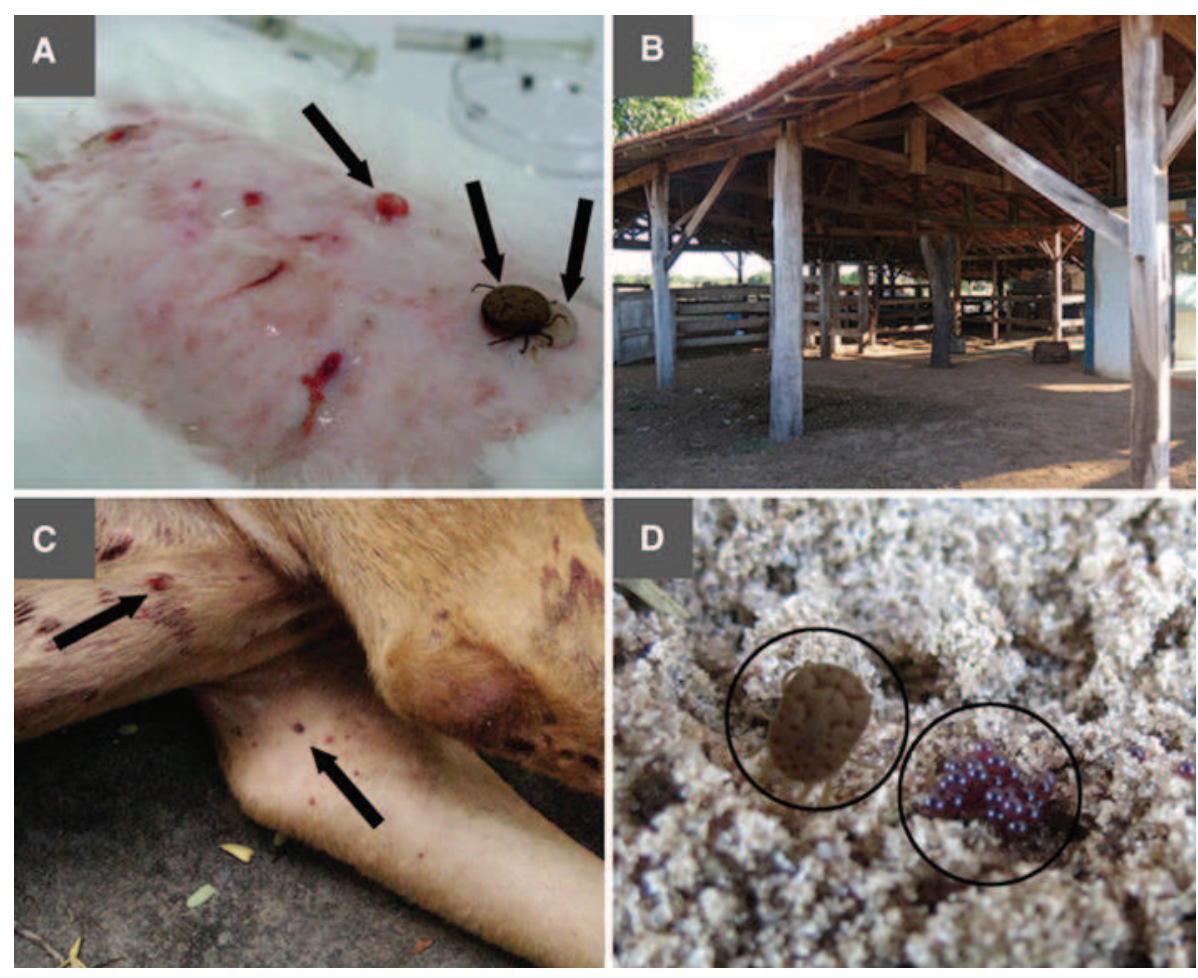

Fig. 1 Host relations of Ornithodoros rostratus in the Pantanal wetland region. a Lesion and emission of coxal fluid during experimental feeding by nymphal instar 5 (arrows). b Partial view of the rustic stable where larvae, nymphs and adults were collected. c Ticks feeding and resulting lesions in an infested dog (arrows). d Female and eggs (circles) seen on the stable floor

to the feeding behavior of nymphs and adults. All specimens were fed individually on a shaved area in the dorsal region of the rabbits in a restraining glass vial to allow full observation of the feeding process. The ticks were cleaned immediately after engorgement and individually placed in 3-ml plastic syringes capped with a cotton plug. A piece of cotton was placed inside the syringe to avoid tick immersion in the coxal fluid and consequent death, as seen at the beginning of the experiment. On the second day after engorgement, the cotton was withdrawn for better observation of ecdyses, which were monitored daily.

A total of 204 nymphs (N1-N5) were individually weighed to the nearest $0.1 \mathrm{mg}$ on an analytical scale (Sartorius BL210 s) before and after engorgement to assess the degree of engorgement. Nine couples were randomly sorted in Petri dishes for mating and females were removed shortly after mating, washed with detergent, dried on absorbent paper and transferred to a new Petri dish for observation of the oviposition. Eggs were collected, counted and weighed daily and separated by oviposition day in 3-ml glass vials with approximately 40 eggs per vial. The vials were monitored daily for the larval hatching process. All free-living stages were maintained under controlled conditions at $27 \pm 1^{\circ} \mathrm{C}$, $80 \pm 10 \%$ relative humidity and in scotophase.

The mean egg production rate was determined based on Bennett (1974). Data on nymphs were statistically analyzed for normality and compared by ANOVA, with the level 
of significance set to $5 \%(p<0.05)$. The experiment received approval from the UFRRJ Ethics Committee for Animal Experimentation, under protocol number 118/2011.

Tick collections and observations in Nhecolândia region

In addition to free ticks collected in November 2006 and August 2007 (Cançado et al. 2008), 44 wild pigs and five dogs owned by the farm employees were examined.

During a third trip, which took place in March 2009, hundreds of ticks were also collected using a shovel to excavate the outer layer of the stable floor, which is made up of dry stool and soil. A dog that used the stable to rest was found heavily parasitized. On a fourth trip made in June 2012, dozens of larvae and 45 nymphs were collected in the $\mathrm{CO}_{2}$ trap and the floor around the trap. Nine females and four males were collected only from the floor and bunches of eggs were also seen on the stable floor (Fig. 1d). At this time, several larvae bit the arms and legs of the collectors.

\section{Results}

Life cycle

A total of $115(53 \%)$ larvae were recovered after a short pre-attachment and feeding periods which lasted an average of $39 \mathrm{~min}$ (range 15-76 min) (Table 1). All 115 (100\%) larvae engorged, but only $94(81.7 \%)$ molted to nymph 1 (N1). A total of 253 nymphs engorged (N1-N5), but only $192(75.9 \%)$ molted to the next instar in the following approximate percentages: $\mathrm{N} 1$ to $\mathrm{N} 2-79 \%, \mathrm{~N} 2$ to $\mathrm{N} 3-79 \%, \mathrm{~N} 3$ to $\mathrm{N} 4$ and adults$75 \%, \mathrm{~N} 4$ to N5 and adults-77\% and N5 to N6 and adults-81\% but only two N5 molted to N6, suggesting that five instars are the rule in the life cycle of $O$. rostratus. Only nymphal instars that fed molted to the next instar and few nymphs (approximately 8-10\%) required a second blood meal to molt but these were discarded. The pre- parasitic and ecdysis periods increased significantly $(p<0.05)$ from N3 to N5 and N1 to N5, respectively. Weight gain increased significantly $(p<0.05)$ from N2 to N5 (Table 1$)$. The analytical scale used was not adequate to measure the weight of first instar nymphs, which weighed less than $0.1 \mathrm{mg}$.

The emergence of 36 adults started with N3 in the following sequence: N3-two males; N4-13 males; N5-three males and 16 females; and N6-two females. Mean weight of $\mathrm{N} 4$ that molted to males was $31.7 \pm 13.6 \mathrm{mg}$, whereas mean weight of $\mathrm{N} 5$ that molted to females was $100.1 \pm 36.2 \mathrm{mg}(p<0.05)$. The overall sex ratio was $1: 1$. The mating of nine couples (fed females and unfed males) was observed off the host in a Petri dish. The pre-mating period, measured from the moment that the male contacted female until the onset of mating, lasted $17.7 \pm 10 \mathrm{~min}$ (range $11-43 \mathrm{~min}$ ). The duration of mating was $14 \pm 7.9$ min (range 9-43 min).

From N2 on, there was emission of coxal fluid while on the host and during or immediately after feeding (Fig. 1a). Table 2 displays the data of engorged females and Fig. 2 displays the mean daily oviposition of nine females. Oviposition lasted 14 days with a considerable variability and a peak on day 3 (Fig. 2). The overall duration of the O. rostratus life cycle ranged from approximately 66 to 136 days (Tables 1 and 2). These calculations did not include intervals between feedings, which demonstrated wide variation, although all specimens were maintained under the same laboratory conditions. For instance, fasting periods ranged from 35 to 45 days for larvae to N5. 
Tick collections and observations in Nhecolândia region

In addition to free ticks collected during the 2007 trip, four nymphs were collected from the belly of one $(2.3 \%)$ wild pig (Sus scrofa) among 44 animals examined, along with a few nymphs from the belly of two out of five dogs examined. During the third trip (March 2009), several nymphs were also collected from a heavily parasitized dog that used the stable to rest. The clinical signs seen in all dogs were disseminated hemorrhagic spots at the biting site (Fig. 1c) and flaccid paralysis in the heavily parasitized dog as well. The employees of the farm complained of fever, the presence of red spots, itching and swelling of the lymph nodes after tick bites. Also, several larvae bit the arms and legs of the collectors, leaving hemorrhagic spots similar to those observed in dogs, accompanied by intense itching that lasted approximately for a week.

\section{Discussion}

Life cycle

The paper offers the first detailed study of the life cycle of $O$. rostratus. In previous papers, authors have relied on rather superficial estimates based on a somewhat inconsistent methodology and different hosts, which hampers comparisons of the findings of the present paper and those described by Brumpt (1915), Guglielmone and Hadani (1980) and Venzal and Estrada-Peña (2006). Nevertheless, similarity is noted in the adult emergence reported by Guglielmone and Hadani (1980) and that found in the present study. The difference in larval feeding performance between the present paper and that described by Venzal and Estrada-Peña (2006) using rabbits as the experimental host as well may be due to the different methodologies employed or even different populations of ticks.

Table 1 Life cycle parameters of larvae and nymphs of Ornithodoros rostratus fed on rabbits

\begin{tabular}{|c|c|c|c|c|c|c|}
\hline Stages & $\begin{array}{l}\text { Prefeeding } \\
\text { (min) }\end{array}$ & $\begin{array}{l}\text { Feeding } \\
(\min )\end{array}$ & $\begin{array}{l}\text { Preecdysis } \\
\text { (days) }\end{array}$ & $\begin{array}{l}\text { Weight } \\
\text { before }(\mathrm{mg})\end{array}$ & $\begin{array}{l}\text { Weight } \\
\text { after (mg) }\end{array}$ & $\begin{array}{l}\text { Weight } \\
\text { gain (mg) }\end{array}$ \\
\hline Larva & $\begin{array}{l}5.2 \pm 2.9 \\
\quad(2-10) 115\end{array}$ & $\begin{array}{l}33.5 \pm 13 \\
\quad(13-66) 115\end{array}$ & $\begin{array}{l}6.8 \pm 1 \\
\quad(5-9) 115\end{array}$ & & & \\
\hline $\begin{array}{l}\text { Nymph } \\
1\end{array}$ & $\begin{array}{r}4.4^{\mathrm{a}} \pm 7.5 \\
\quad(1-35) 71\end{array}$ & $\begin{array}{r}17.3^{\mathrm{a}} \pm 7.0 \\
(3-45) 71\end{array}$ & $\begin{array}{l}5.7^{\mathrm{a}} \pm 1.2 \\
(3-10) 71\end{array}$ & & & \\
\hline $\begin{array}{l}\text { Nymph } \\
2\end{array}$ & $\begin{array}{c}10.6^{\mathrm{b}, \mathrm{c}} \pm 10.9 \\
(1-45) 60\end{array}$ & $\begin{array}{r}19.8^{\mathrm{a}} \pm 8.3 \\
(3-43) 60\end{array}$ & $\begin{array}{r}7.31^{b} \pm 0.5 \\
(6-12) 60\end{array}$ & $\begin{array}{l}0.9^{\mathrm{a}} \pm 0.5 \\
\quad(0.3-3.5) 49\end{array}$ & $\begin{array}{l}4.1^{\mathrm{a}, \mathrm{b}} \pm 2.1 \\
\quad(0.7-11) 49\end{array}$ & $\begin{array}{l}3.2^{\mathrm{a}, \mathrm{b}} \pm 1.8 \\
\quad(0.2-7.5) 49\end{array}$ \\
\hline $\begin{array}{l}\text { Nymph } \\
3\end{array}$ & $\begin{array}{c}10.2^{\mathrm{b}, \mathrm{c}} \pm 8.8 \\
\quad(1-37) 52\end{array}$ & $\begin{array}{l}22.0^{\mathrm{a}} \pm 11.1 \\
\quad(7-48) 52\end{array}$ & $\begin{array}{r}16.1^{\mathrm{c}} \pm 3.3 \\
(6-20) 52\end{array}$ & $\begin{array}{l}3.0^{\mathrm{b}} \pm 1.3 \\
\quad(0.4-6.4) 67\end{array}$ & $\begin{array}{r}10.7^{\mathrm{b}} \pm 5.9 \\
(2-35) 67\end{array}$ & $\begin{array}{l}7.6^{\mathrm{b}} \pm 5.4 \\
(0.5-31.9) \\
67\end{array}$ \\
\hline $\begin{array}{l}\text { Nymph } \\
4\end{array}$ & $\begin{array}{c}15.7^{\mathrm{c}} \pm 16.2 \\
(1-59) 44\end{array}$ & $\begin{array}{c}31.5^{\mathrm{b}} \pm 13.0 \\
(6-61) 44\end{array}$ & $\begin{array}{r}10.4^{\mathrm{c}} \pm 2.2 \\
(7-16) 44\end{array}$ & $\begin{array}{l}7.4^{\mathrm{c}} \pm 2.9 \\
\quad(1.7-15.4) \\
56\end{array}$ & $\begin{array}{l}29.4^{\mathrm{c}} \pm 12.7 \\
\quad(6.8-59.7) 56\end{array}$ & $\begin{array}{l}22^{\mathrm{c}} \pm 10.4 \\
\quad(2.1-44.9) \\
56\end{array}$ \\
\hline$\underset{5}{\text { Nymph }}$ & $\begin{array}{r}6.4^{\mathrm{a}, \mathrm{b}} \pm 5.9 \\
\quad(1-28) 26\end{array}$ & $\begin{array}{r}39.2^{\mathrm{c}} \pm 11.4 \\
(21-65) 26\end{array}$ & $\begin{array}{r}13.3^{d} \pm 2.7 \\
(8-17) 26\end{array}$ & $\begin{array}{l}18.1^{\mathrm{d}} \pm 7.0 \\
\quad(1.3-30.4) \\
32\end{array}$ & $\begin{array}{l}76.2^{\mathrm{d}} \pm 42.2 \\
(17.5-167.1) \\
32\end{array}$ & $\begin{array}{l}58.1^{\mathrm{d}} \pm 37 \\
\quad(4.9-136.7) \\
32\end{array}$ \\
\hline
\end{tabular}

Horizontal sequences: mean $\pm \mathrm{SD}$, range (in parentheses) and $\mathrm{N}$

Means within a column followed by different letters are significantly different $(p<0.05)$ 
Table 2 Life cycle parameters of Ornithodoros rostratus engorged females. Horizontal sequence: mean $\pm \mathrm{SD}$, range (in parentheses) and number of females before oviposition (17), number of females that oviposited viable eggs (9) and number of vials with approximately 40 larvae each (71)

\begin{tabular}{ll}
\hline Parameters & Values \\
\hline Prefeeding (min) & $6.4 \pm 4.8(1-20) 17$ \\
Feeding (min) & $45.4 \pm 14.6(22-3) 17$ \\
Weight before feeding (mg) & $58.5 \pm 17.1(29-97) 17$ \\
Weight after feeding (mg) & $210.4 \pm 69.7(43-359) 17$ \\
Weight gain (mg) & $150.1 \pm 55(14-262) 17$ \\
Pre-oviposition (days) & $8.2 \pm 1.2(7-10) 9$ \\
Oviposition (days) & $10 \pm 3(6-14) 9$ \\
Weight of egg mass (mg) & $58.8 \pm 18(31-81) 9$ \\
Eggs per oviposition & $555.5 \pm 148.2(277-717) 9$ \\
Egg production index (\%) & $27.8 \pm 4.9(20-33) 9$ \\
Pre-hatching (days) & $12.7 \pm 0.5(12-13) 71$ \\
Hatching (days) & $7.7 \pm 2.9(6-15) 71$ \\
Eclosion (\%) & $75.9 \pm 19.3(44-99) 71$ \\
\hline
\end{tabular}

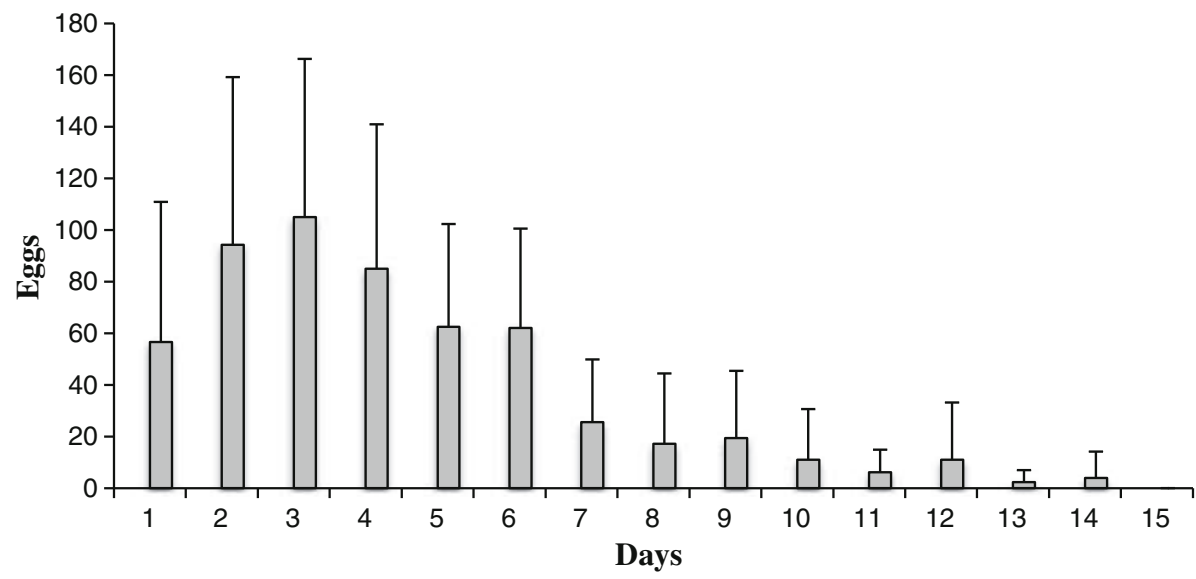

Fig. 2 Daily mean (+SD) oviposition of nine Ornithodoros rostratus females

The life cycle of $O$. rostratus is similar to that of most species of Ornithodoros that parasitize land mammals (Hoogstraal 1985), with rapid feeding in all stages and long intervals between molts. Species of the genus Ornithodoros are grouped into three classes according to larval feeding pattern: (1) larvae molt to N1 without feeding [e.g., O. savignyi Audouin (Khan and Srivastava 1988) and O. brasiliensis (Barros-Battesti et al. 2012)]; (2) larvae feed for a few minutes [e.g., O. rostratus (present paper) and O. turicata (Beck et al.1986)]; and (3) larvae that feed slowly for many days, as in species that parasitize bats and birds (Landulfo et al. 2012).

Feeding once before molting was commonly required for all nymphal instars but in some occasions, nymphs fed more than once before ecdysis. According to Hoogstraal (1985), nymphs can feed more than once before the ecdysis process, because the first blood meal may have been interrupted or insufficient for molting. The emergence of adults in this experiment, with males emerging before females, is also a common pattern for the genus 
Ornithodoros (Balashov 1972). However, differences are found in the number of emerged adults, for instance, in $O$. parkeri (Pound et al. 1986) females emerged from N4 and N5 but only from N5 in this paper.

The mating sequence occurred in the same manner as that described by Balashov (1972), the male probes the female with its first pair of legs, climbs on the back of the female, moves to the ventral surface of the female and transfers the spermatophores to open female genital aperture.

Tick collections and observations in Nhecolândia region

This was the first report of $O$. rostratus parasitizing wild pigs and dogs in the Pantanal region. The finding of only one infested animal (2.3\%) among the 44 wild pigs examined suggests that these animals are not the primary host for $O$. rostratus in the region, probably due to the high degree of vagility of pigs, contrasting the nidicolous habits of the tick. On the other hand, parasitized dogs used the stable as a resting place, apparently an adequate shelter for $O$. rostratus. The hemorrhagic spots seen in natural infestations have also been experimentally reproduced in rabbits (Fig. 1a). These signs are rather common results of argasid ticks feeding. Furthermore, signs of flaccid paralysis seen in the heavily parasitized dog are compatible with the "tick toxicosis" described by Reck et al. (2011) in a dog infested by $O$. brasiliensis in the state of Rio Grande do Sul, Brazil.

Acknowledgments This study was supported by the Brazilian agencies Conselho Nacional de Desenvolvimento Científico e Tecnológico (CNPq) and Coordenação de Aperfeiçoamento de Pessoal de Nível Superior (CAPES).

\section{References}

Almeida AP, Marcili A, Leite RC, Nieri-Bastos FA, Domingues LN, Martins JR, Labruna MB (2012) Coxiella symbiont in the tick Ornithodoros rostratus (Acari: Argasidae). Ticks Tick Borne Dis 3:203-206

Balashov YS (1972) Blood-sucking ticks (Ixodoidea) vectors of diseases of man and animals. Misc Publ Entomol Soc Am 8:161-376

Barros-Battesti DM, Onofrio VC, Nieri-Bastos FA, Soares JF, Marcili A, Famadas KM, Faccini JLH, Ramirez DG, Doyle RL, Martins JR, Reck J, Guglielmone AA, Labruna MB (2012) Ornithodoros brasiliensis Aragão (Acari: Argasidae) description of the larva, redescription of male and female, and neotype designation. Zootaxa (Auckland. Print) 3178:22-32

Beck AF, Holscher KH, Butler J (1986) Life cycle of Ornithodoros turicata americanus (Acari: Argasidae) in the laboratory. J Med Entomol 23:313-319

Bennett GF (1974) Oviposition of Boophilus microplus (Canestrini) (Acarida: Ixodidae): (influence of tick size on egg production). Acarology 16:52-61

Brumpt E (1915) Biologia de alguns Ixodideos Brasileiros. Ann Paul Med Cir 4:25-29

Cançado PHD, Piranda EM, Mourão GM, Faccini JLH (2008) Spatial distribution and impact of cattleraising on ticks in the Pantanal region of Brazil by using the $\mathrm{CO}_{2}$ tick trap. Parasitol Res 103:371-377

Dantas-Torres F, Venzal JM, Bernardi LFO, Ferreira RL, Onofrio VC, Marcili A, Bermúdez SE, Ribeiro AF, Barros-Battesti DM, Labruna MB (2012) Description of a new species of bat-associated argasid tick (Acari: Argasidae) from Brazil. J Parasitol 98:36-45

Davis GE (1952) Observations on the biology of the Argasid tick, Ornithodoros brasiliensis Aragão, 1923, with the recovery of a spirochete, Borrelia brasiliensis, n. sp. J Parasitol 38:473-476

Guglielmone AA, Hadani H (1980) Ciclo biológico de Ornithodoros rostratus (Aragão, 1911) bajo condiciones de laboratório. Medicina Veterinária 61:254-257

Guglielmone AA, Robins RG, Apanaskevich DA, Petney TN, Estrada-Peña A, Horak IG, Shao R, Barker SC (2010) The Argasidae, Ixodidae and Nuttalliellidae (Acari: Ixodida) of the world: a list of valid species names. Zootaxa 2528:1-28 
Hoogstraal H (1985) Argasid and Nutalliellid ticks as parasites and vectors. Adv Parasitol 24:135-238 Khan MH, Srivastava SC (1988) Life-history of Ornithodoros savignyi Audoun. Ind Vet J 65:192-195 Landulfo GA, Pevidor LV, Sampaio JS, Luz HR, Onofrio VC, Faccini JLH, Barros-Battesti DM (2012) Life cycle of Ornithodoros mimon (Acari: Argasidae) under laboratory conditions. Exp Appl Acarol 58:69-80

Pound JM, Campbell JD, Andrews RH, Oliver JH Jr (1986) The relationship between weights of nymphal stages and subsequent development of Ornithodoros parkeri (Acari: Argasidae). J Med Entomol 23:320-325

Reck J, Soares JF, Termignoni C, Labruna MB, Martins JR (2011) Tick toxicosis in a dog bitten by Ornithodoros brasiliensis. Vet Clin Path 40:356-360

Schumaker TTS, Barros DM (1995) Life cycle of Ornithodoros (Alectorobios) talaje (Acari: Argasidae) in laboratory. J Med Entomol 32:249-254

Venzal JM, Estrada-Peña A (2006) Larval feeding performance of two Neotropical Ornithodoros ticks (Acari: Argasidae) on reptiles. Exp Appl Acarol 39:315-320 